\title{
Evaluation of prescription indicators established by the WHO in Getúlio Vargas - RS
}

\author{
Andressa Tanise $\operatorname{Vooss}^{1 *}$, Helissara Silveira Diefenthaeler ${ }^{1}$ \\ ${ }^{1}$ Regional Integrated University of Alto Uruguai and Missões (URI), Erechim Campus, Rio Grande do Sul
}

\begin{abstract}
To evaluate the conditions of the services offered to the community regarding medications, the World Health Organization (WHO) has developed the Medication Use Indicators, among them Prescription indicators. The objective of this study was to evaluate drug prescriptions in a Basic Health Care Center in Getúlio Vargas - RS, according to the Prescription Indicators recommended by the WHO. The data collection was performed with the use of a form and the prescriptions for June / July and November / December 2008 were evaluated. The average number of drugs prescribed was 2.03 , and $72.8 \%$ of the drugs were prescribed by generic name, $80.3 \%$ were on the list of essential drugs, $21.7 \%$ were antibiotics and $2.4 \%$ were injectable drugs. The results were in accordance with WHO recommendations and were similar to those reported by other studies.
\end{abstract}

Uniterms: Medications/rational use. Medications/prescription indicators. World Health Organization/ medication use indicators.

\begin{abstract}
Para avaliar as condições dos serviços prestados à população no que se refere aos medicamentos, a Organização Mundial da Saúde (OMS) desenvolveu Indicadores do uso de Medicamentos, entre eles os de Prescrição. O objetivo da pesquisa foi avaliar prescrições medicamentosas de usuários de uma Unidade Básica de Saúde do município de Getúlio Vargas - RS conforme os Indicadores de Prescrição preconizados pela OMS. A coleta de dados foi realizada com uma ficha. Para isso houve acesso as prescrições atendidas no período de junho/julho e de novembro/dezembro de 2008. A média de medicamentos prescritos foi de 2,03, 72,8\% dos medicamentos foram prescritos pelo nome genérico, 80,3\% constavam na lista dos medicamentos essenciais, $21,7 \%$ eram antibióticos e 2,4\% injetáveis. Observou-se que os resultados obtidos estão de acordo com os recomendados pela OMS e que foram similares a outros estudos.
\end{abstract}

Unitermos: Medicamentos/uso racional. Medicamentos/indicadores de Prescrição. Organização Mundial da Saúde/indicadores do uso de medicamentos.

\section{INTRODUCTION}

The rational use of medications is a worldwide concern, and is therefore prominent among heath care professionals. Concerted efforts to readjust pharmaceutical actions and practices aiming at the rational use of medication are essential in today's society, in which drugs are the most used therapeutic resource. Aiming to evaluate the conditions of the services offered to the population concerning medication, the World Health

\footnotetext{
*Correspondence: A. T. Vooss, Universidade Regional Integrada do Alto Uruguai e das Missões, Av. Sete de Setembro, 1621, 99700-000 - Erechim - RS, Brasil. E-mail: andressatanise@yahoo.com.br
}

Organization (WHO) developed Medication Use Indicators, including Prescription Indicators (Bernardi, Bieberbach, Thomé, 2006).

Prescription Indicators allow the therapeutic actions taken in similar institutions to be ascertained, enabling subsequent comparison of parameters between them, and to evaluate the population's medication needs and determine the most frequently used medications in a given place (Farias et al., 2007). In addition, these indicators allow identification of the prescription profile and quality of services offered to the population.

The prescription Indicators are as follows (Farias et al., 2007). 


\section{Medication average per medical prescription}

Through this indicator it is possible to investigate polymedication, a major factor contributing to drug interactions and adverse reactions. The educational and informational level of the person prescribing the medication may also be observed (Oliveira et al., 2009; Farias et al., 2007; Carmo, Nitrini, 2004; Santos, Nitrini, 2004; Bontempo et al., 2003; Cunha, Zorzatto, Castro, 2002).

\section{Percentage of medication prescribed with generic name}

This indicator allows the calculation of the number of prescriptions in which the drugs are prescribed with the generic name, as determined by the current National Drug Policy (NDP) of October 1998. Thus, it is possible to control drug costs in the health service, due to the fact that the drugs of general references are more expensive. Also, it evaluates the marketing influence on the person prescribing drugs (Oliveira et al., 2009; Farias et al., 2007; Carmo, Nitrini, 2004; Santos, Nitrini, 2004; Bontempo et al., 2003; Cunha, Zorzatto, Castro, 2002).

\section{Percentage of prescribed drugs from list of essential drugs}

Besides controlling costs, the essential drugs list guarantees the treatment of the principal diseases of the population.

\section{Percentage of prescribed antibiotics}

This indicator aims to evaluate the use of antibiotics in excess, a practice which contributes to bacterial dissemination and resistance. (Oliveira et al., 2009; Farias et al., 2007; Carmo, Nitrini, 2004; Santos, Nitrini, 2004; Bontempo et al., 2003).

\section{Percentage of prescribed injectable drugs}

This indicator aims to evaluate the injectables in excess because their administration may have serious consequences when prescribed or applied wrongly, such as difficulty for case reversion in the event of anaphylactic reactions, adverse reactions, fiber necrosis, etc. (Oliveira et al., 2009; Farias et al., 2007; Carmo, Nitrini, 2004; Santos, Nitrini, 2004).

With these indicators, it is possible to swiftly and safely evaluate the attention given to health, but these indicators do not quantify all the important aspects of drug use (Carmo, Farhat, Alves, 2003).
Studies applying the WHO Prescription Indicators have been conducted in many cities in Brazil. This has enabled evaluation of the conditions of the offered services concerning medication and also allowed comparison and identification of differences in the regions. In many studies, the authors found good results regarding the Prescription Indicators, possibly as a consequence of the National Drug Policy and the holding of the Drugs and Pharmaceutical Assistance City conference (Farias et al., 2007). Nevertheless, the Prescription Indicators of many cities are still needed in order to compare the Pharmaceutical Assistance services among them.

The aim of this study was to evaluate the Prescription Indicators approved by the WHO in a Health Care Center in Getúlio Vargas -RS. This town has about 16,506 inhabitants and five Health Care Centers, which provide completely free medication distribution through a health assistance program of the government (Getúlio Vargas, 2009).

\section{MATERIAL AND METHODS}

A transversal study design was used and the sample comprised all the medication prescriptions made out at a Health Care Center drugstore in Getúlio Vargas - RS.

As the South of Brazil has a colder and more intense winter in comparison to other regions of the country, diseases such as respiratory illnesses are more often seen in this season. Thus, a higher percentage of drug prescriptions is expected, particularly injectables and those containing antibiotics. Aiming to compare the differences between the Prescription Indicators, it was chosen to evaluate prescriptions of two seasonal periods. Therefore, the data was collected from prescriptions in June and July, 2008, which were the winter prescriptions, and in November and December, 2008, which were the summer prescriptions.

The data collection was done using a tailored form. For this collection, the prescriptions made out during the specified period were assessed and therefore patients were not questioned.

The variables of interest in this study were: number of medications in each prescription, percentage of prescribed drugs with generic name, percentage of prescribed drugs on the list of the City's essential medications, percentage of prescribed antibiotics and injectables.

The data was analyzed on the statistical computer software program, SPSS (Statistical Package of the Social Sciences) v.16.0 for Windows. To achieve this, distribution calculations were used (average and frequency). The Chisquared and $P$ tests were employed. Difference with $P<$ 0.05 were considered to be significant. 
This research was approved by the Regional Integrada doAlto Uruguai e das Missões - URI Campus de Erechim University Research Ethical Committee in Erechim, RS, under registration number 176/TCH/08.

\section{RESULTS}

In this study, 1,030 prescriptions were analyzed from a total of 2,090 medical prescriptions and average number of medications per prescription was 2.03. Table I shows the number of medications in each prescription.

TABLE I - Number of medication in each prescription

\begin{tabular}{lcc}
\hline Number of medications & N (prescriptions) & $\mathbf{\%}$ \\
\hline 1 & 488 & 47.4 \\
2 & 236 & 22.9 \\
3 & 164 & 15.9 \\
4 & 97 & 9.4 \\
5 & 30 & 2.9 \\
6 & 11 & 1.1 \\
7 & 1 & 0.1 \\
8 & 1 & 0.1 \\
9 & 1 & 0.1 \\
10 & 1 & 0.1 \\
Total & 1030 & 100.0 \\
\hline
\end{tabular}

The prescription of 189 different medications was observed, the most frequent being diclofenac sodium and acetaminofen, both corresponding to $36.5 \%$ of the total. Other most frequently prescribed medications are shown in Table II.

TABLE II - Medications most frequently prescribed

\begin{tabular}{lcc}
\hline Medication & $\mathbf{N}$ & $\mathbf{\%}$ \\
\hline Diclofenac sodium $50 \mathrm{mg}$ & 147 & 14.3 \\
Acetaminofen $500 \mathrm{mg}$ & 120 & 11.7 \\
Acetaminofen $200 \mathrm{mg} / \mathrm{mL}$ & 108 & 10.5 \\
Omeprazole $20 \mathrm{mg}$ & 95 & 8.9 \\
Cephalexin $500 \mathrm{mg}$ & 75 & 7.3 \\
Others & 489 & 47.3 \\
Total & 1030 & 100 \\
\hline
\end{tabular}

The more prevalent therapeutic categories included analgesics (22.2\%), anti-inflammatory (14.3\%) anti-ulcer $(9.9 \%)$ and antibiotics (7.3\%).
The percentage of medications prescribed with the generic name was $72.8 \%$ and the percentage of prescribed medications appearing in the list of essential medication was $80.3 \%$. Antibiotics were prescribed in $21.7 \%$ of the prescriptions, and the prevalent antibiotics are shown in Table III.

TABLE III - Prevalent Antibiotics

\begin{tabular}{lll}
\hline Medication & $\mathbf{N}$ & $\mathbf{\%}$ \\
\hline Cephalexin $500 \mathrm{mg}$ & 75 & 7.3 \\
Amoxicilin $500 \mathrm{mg}$ & 46 & 4.5 \\
Amoxicillin $250 \mathrm{mg}$ & 27 & 2.6 \\
Cephalexin $250 \mathrm{mg}$ & 21 & 2.0 \\
Neomycin & 12 & 1.2 \\
Others & 42 & 4.1 \\
Total & 223 & 21.7 \\
\hline
\end{tabular}

Only 25 prescriptions (2.4\%), had injectables prescribed and no more than one injectable was prescribed in each prescription. The predominant injectables are shown in the Table IV.

TABLE IV - Predominant injectables

\begin{tabular}{lcc}
\hline Medication & N & \% \\
\hline Benzilpeniciliin benzathine & 5 & 0.5 \\
Medroxyprogesterone 150 mg & 4 & 0.4 \\
Piroxicam $40 \mathrm{mg}$ & 4 & 0.4 \\
Meloxicam $15 \mathrm{mg}$ & 3 & 0.3 \\
*Hydroxocobalamin/Dexamethasone/Dipyrone & 2 & 0.2 \\
Others & 7 & 0.6 \\
Total & 25 & 2.4 \\
\hline
\end{tabular}

* Injectable solution composition: each ampoule 1 contains hydroxocobalamin (vit B12) $500 \mathrm{mg}$. Each ampoule II contains 21 - dexamethasone disodium phosphate $1.5 \mathrm{mg}$, dipyrone $500 \mathrm{mg}$, vehicle q.s.p $1 \mathrm{~mL}$.

Table $\mathrm{V}$ shows the differences found in prescriptions corresponding to the months of winter and summer.

\section{DISCUSSION}

A total of 1,030 prescriptions were studied most of which had only one medication prescribed (47.4\%). However, there were 4 prescriptions $(0.6 \%)$ in which more than 6 medications were prescribed according to 
TABLE V - Differences observed in prescriptions corresponding to Winter and Summer

\begin{tabular}{lcc}
\hline & Winter & Summer \\
\hline Number of prescriptions & 534 & 496 \\
$\begin{array}{l}\text { Average no. of medications in each } \\
\text { prescription }\end{array}$ & 2.12 & 1.95 \\
\% Generic name & 72.0 & 73.6 \\
\% Essential medication list & 80.0 & 80.4 \\
\% Antibiotics & 23.4 & 19.8 \\
\% Injectables & 3.0 & 1.8 \\
\hline
\end{tabular}

Table I. Similarly, in the study of Oliveira et al. (2009) it was observed that most prescriptions also had only one medication prescribed. However, in the Ev, Guimarães and Castro (2008) study, 34.27\% of the prescriptions had one medication prescribed and $34.37 \%$ had 2 medication prescribed, thus differing from the present study.

The average number of medications in each prescription was 2.03 and this is in accordance with the WHO's recommendation, which is 2 or less. We can conclude that there were no problems of polymedication and adverse reactions because the average medication in each prescription in this study was in accordance with WHO recommendations.

The medications most often prescribed in this study are shown in Table II. The study by Colombo et al. (2004), as did this study, found diclofenac and acetaminofen to be the most often prescribed, both corresponding to $22.6 \%$. Other studies report these results by pharmacologic groups, where the more often prescribed medications are those for the respiratory and nervous system. (Girotto, Silva, 2006; Naves, Silver, 2005; Felício, 2007; Farias et $a l ., 2007)$. We observed in this study that the prevalent therapeutic categories are compatible with the medications most often prescribed: analgesics $(22.2 \%)$ anti inflammatory $(14.3 \%)$, anti tuberculosis $(8.9 \%)$ and antibiotics (7.3\%) and the difference between the prevalent pharmacologic categories in this, and the other studies cited, is clear, which may be attributed to the differences among the regions where the research was carried out and the pathologies that appeared in the population.

The percentage of medications prescribed with the generic name was $72.8 \%$ where the WHO establishes this at $100 \%$. This low percentage of prescribed medications with the generic name may be explained because of the high investment of the pharmaceutical industry in advertising their medications and this may influence prescribers. Moreover, we should point out that some medications appear in the local list under their commercial name, which may deter professionals from using the generic name.

A total of $80.3 \%$ of the prescribed medications were from the list of the essentials medications which is in compliance with the percentage recommended by the WHO of $70 \%$. This indicator reveals that the standardized medications are being prescribed and are also covering most of the pathologies of the patients treated at the studied health care center. Thus, it can be assumed that essential medications are accessible to the population.

Antibiotics were prescribed in $21.7 \%$ of the prescriptions and the most prevalent antibiotics are shown in Table III. The problem with antibiotics use is the bacterial resistance caused when there is inappropriate or excessive use. The indicator result is above the level approved by the $\mathrm{WHO}$, which is $20 \%$ or less, but the figure found does not constitute excessive prescription.

Injectable medications were prescribed in $2.4 \%$ of the analyzed prescriptions and the predominant injectables are shown in Table IV. The WHO establishes the prescription of $10 \%$ injectables, and the percentage found in this study fell below this level. As observed in Table V, the prescription of injectables in the Winter was almost double (40\%), compared with the Summer, and this finding is in accordance with Farias et al. (2007) study in which the percentage of injectables was $1.1 \%$ where this low percentage was attributed to the hot season of the year. Other hypotheses for the low prescription of injectables may be because they appear in low quantities and varieties in the city's list of essential medications.

Although the prescription percentage of antibiotics and injectable drugs was found to be higher in the Winter, this difference was not significant $(\mathrm{P}>0.05)$. This result may suggest that there were no changes in the pattern of morbidity which justify a significant increase in the prescription of these drugs in the Winter. However, the morbidity epidemiologic data was not collected for comparison.

Table VI provides a comparison between this study and other studies and reveals that the result for Prescriptions Indicators are similar among the different Brazilian cities, and bar some exceptions, all the studies were in accordance with the WHO's recommendations.

\section{CONCLUSION}

This study showed that in the Health Care Center of Getúlio Vargas - RS, where the study was carried out, most of the indicators analyzed were in accordance with the WHO's recommendations, except the percentage of medications prescribed with the generic name and the percentage of injectables. However, these two indicators were in line with other studies performed in different 
TABLE VI - Comparison between studies conducted in different cities of Brazil

\begin{tabular}{|c|c|c|c|c|c|c|c|c|c|}
\hline Authors & $\begin{array}{c}\text { Our } \\
\text { study }\end{array}$ & Felício & $\begin{array}{l}\text { Girotto; } \\
\text { Silva }\end{array}$ & $\begin{array}{l}\text { Farias } \\
\text { et al. }\end{array}$ & $\begin{array}{l}\text { Naves; } \\
\text { Silver }\end{array}$ & $\begin{array}{c}\text { Colombo } \\
\text { et al. }\end{array}$ & Marcondes & Consedey & $\begin{array}{c}\text { WHO } \\
\text { recommendec }\end{array}$ \\
\hline Cities & $\begin{array}{c}\text { Getúlio } \\
\text { Vargas, } \\
\text { RS (2009) }\end{array}$ & $\begin{array}{l}\text { Franca, } \\
\text { SP (2007) }\end{array}$ & $\begin{array}{l}\text { Ibiporã } \\
\text { PR (2006) }\end{array}$ & $\begin{array}{l}\text { Campina } \\
\text { Grande, } \\
\text { PB (2005) }\end{array}$ & $\begin{array}{l}\text { Brasília, } \\
\text { DF (2005) }\end{array}$ & $\begin{array}{l}\text { Blumenau, } \\
\text { SC (2004) }\end{array}$ & $\begin{array}{l}\text { Ponta } \\
\text { Grossa, PR } \\
(2002)\end{array}$ & $\begin{array}{l}5 \text { states: AC, } \\
\text { AM, GO, PE, } \\
\text { RJ (2000) }\end{array}$ & - \\
\hline $\begin{array}{l}\text { Average no. of } \\
\text { medications per } \\
\text { prescription }\end{array}$ & 2.03 & 2.0 & 2.0 & 1.5 & 2.3 & 1.8 & 2.6 & 2.11 & 2.0 or less \\
\hline$\%$ Generic name & 72.8 & 65.5 & 70.2 & 84.2 & 73.2 & $\begin{array}{c}\text { Not } \\
\text { collected }\end{array}$ & 71 & 69.42 & 100 \\
\hline $\begin{array}{l}\% \text { Essential } \\
\text { Medication List }\end{array}$ & 80.3 & 68.2 & 58.4 & 91.9 & 85.3 & 82.4 & 87 & 68.02 & 70 \\
\hline$\%$ Antibiotic & 21.7 & 28.1 & 22.0 & 21.1 & 26.4 & 12.5 & 33 & 39.21 & 2.0 or less \\
\hline \% Injectables & 2.4 & 4.8 & 7.0 & 1.1 & 7.5 & 8.1 & 13 & 11.60 & 10 \\
\hline
\end{tabular}

Brazilian cities, which also showed good results compared with the WHO recommendations and with other health care centers analyzed.

To adjust the percentage indicator of the prescribed medications with the generic name, prescribers must be aware of this and principally that the medications in the city's essential medications list appear under their generic name in accordance with the NPD, whereas the commercial name is used in current lists.

These results allow the conclusion that through studies using the Prescription Indicators recommended by the WHO, it is possible to evaluate the conditions of the offered services concerning medications and also to compare and identify differences among regions. Thus, it can be asserted that the Prescription Indicators can help the Heath Care Centers to obtain better organization and improve healthcare attention to the public.

\section{REFERENCES}

BERNARDI, C.L.B.; BIEBERBACH, E.W.; THOMÉ, H.I. Avaliação da Assistência Farmacêutica Básica nos Municípios de Abrangência da $17^{\mathrm{a}}$ Coordenadoria Regional de Saúde do Rio Grande do Sul. Saúde Soc. São Paulo, v.15, n.1, p.73-83, 2006.

BONTEMPO, V.L.; COELHO, M.C.; CHAVES, J.G.; PEREIRA, L.A.M.; ANDRADE, W.W.; BRACCINI, C.M. Análise das prescrições geradas pelas equipes do PSF e das Unidades de Atendimento Imediato, em dois distritos sanitários do município de Contagem/MG. Bol. Pneumol. Sanit., v.11, n.2, p.17-24, 2003.
BRASIL. Portaria n ${ }^{\circ} 3916$, de 30 de outubro de 1998. Aprova a Política Nacional de Medicamentos, cuja íntegra consta do anexo desta Portaria. Diário Oficial da União, Brasília, DF, 10 nov. 1998. Available at: < http://e-legis.anvisa.gov. br/leisref/public/showAct.php?id=751> Accessed on: 20 may 2009.

CARMO, T.A.; FARHAT, F.C.L.G.; ALVES, J.M. Indicadores de Prescrições Medicamentosas: ferramentas para intervenção. Saúde Rev., v.5, n.11, p.49-55, 2003.

CARMO, T.A.; NITRINI, S.M.O.O. Prescrições de medicamentos para gestantes: um estudo farmacoepidemiológico. $\mathrm{Cad}$. Saúde Pública, v.20, n.4, p.1004-1013, 2004.

\section{CENTRO BRASILEIRO DE INFORMAÇÃO SOBRE} MEDICAMENTOS (CEBRIM). Promovendo o uso racional dos medicamentos: principais componentes. Bol. Farmacoterapêtica, v.8, n.1, p.38-43, 2003.

COLOMBO, D.; HELENA, E.T.S.; AGOSTINHO, A.C.M.G; DIDJURGEIT, J.S.M.A. Padrão de Prescrição de Medicamentos nas Unidades de Programa de Saúde da Família de Blumenau. Rev. Bras. Ciênc. Farm., v.40, n.4, p.549-558, 2004.

COSENDEY M.A.E. Análise da implantação do Programa Farmácia Básica: um estudo multicêntrico em cinco estados do Brasil. Rio de Janeiro, 2000. $366 \mathrm{f}$. [Thesis of $\mathrm{PhD}$ degree in Public Health. Oswaldo Cruz Foundation/ National School of Public Health]. 
CUNHA, M.C.N.; ZORZATTO, J.R.; CASTRO, L.L.C. Avaliação do uso de medicamentos na Rede Pública Municipal de Saúde de Campo Grande/MS. Rev. Bras. Ciênc. Farm., v.38, n.2, p.215-227, 2002.

EV, L.S.; GUIMARÃES, A.G.; CASTRO, V.S. Avaliação das prescrições dispensadas em uma Unidade Básica de Saúde do Município de Ouro Preto, Minas Gerais, Brasil. Lat. Am. J. Pharm., v.27, n.4, p.543-547, 2008.

FARIAS, A.D.; CARDOSO, M.A.A.; MEDEIROS, A.C.D.; BELÉM, L.F; SIMÕES, M.O.S. Indicadores de prescrição médica nas unidades básicas de Saúde da Família no município de Campina Grande, PB. Rev. Bras. Epidemiol., v.10, n.2, p.149-156, 2007.

FELICIO, N. Farmacoepidemiologia da prescrição e dispensação de medicamentos na rede pública municipal de saúde de Patos de Minas/MG Franca. Franca, 2007. 117 f. [Dissertação de Mestrado em Promoção de Saúde. Universidade de Franca].

GETÚLIO VARGAS. Geografia. Available at: < http://www. pmgv.rs.gov.br/geografia. html>Accessed on: 01 jun. 2009.
GIROTTO, E.; SILVA, P.V. A prescrição de medicamentos em um município do Norte do Paraná. Rev. Bras. Epidemiol., v.9, n.2, p.226-234, jun. 2006.

MARCONDES, N.S.P. A Assistência Farmacêutica e o uso de medicamentos na zona urbana do Município de Ponta Grossa Paraná: estudo de caso. Rio de Janeiro, 2002. 170 f. [Dissertação de Mestrado em Saúde Pública. Universidade Estadual de Ponta Grossa/Fundação Oswaldo Cruz].

NAVES, J.O.S.; SILVER L.D. Evaluation of pharmaceutical assistance in public primary care in Brasília, Brazil. Rev. Saúde Pública, v.39, n.2, p.223-230, 2005.

OLIVEIRA, C.A.P.; MARIN, M.J.S.; MARCHIOLI, M.; PIZOLETTO, B.H.M.; SANTOS, R.V. Caracterização dos medicamentos prescritos aos idosos na Estratégia Saúde da Família. Cad. Saúde Pública, v.25, n.5, p.1007-1016, 2009.

SANTOS, V.; NITRINI, S.M.O.O. Indicadores do uso de medicamentos prescritos e de assistência ao paciente de serviços de saúde. Rev. Saúde Pública, v.38, n.6, p.819826, 2004.

Received for publication on $03^{\text {rd }}$ August 2010 Accepted for publication on $12^{\text {th }}$ January 2011 